\title{
Combining ability analysis of yield and resistance to late blight disease caused by Phytophthora infestans in Uganda
}

\author{
Prossy Namugga* ${ }^{1,2}$, Julia Sibiya ${ }^{1}$, Rob Melis ${ }^{1}$, and Alex Barekye ${ }^{2}$ \\ ${ }^{1}$ African Centre for Crop Improvement, University of KwaZulu-Natal, School of Agricultural, Earth and \\ Environmental Sciences, Private Bag X01, Scottsville 3209, Pietermaritzburg, South Africa \\ ${ }^{2}$ National Agricultural Research Organisation (NARO), P.O.Box 421 Kabale, Uganda
}

\author{
*Correspondence: namuggak@gmail.com
}

\begin{abstract}
Breeding for resistance to late blight disease caused by Phytophthora infestans (Mont.) de Bary in potato is the most economically, effective and ecologically sustainable method to control the disease and boost productivity. The study estimated combining ability effects of yield, yield related traits, late blight resistance and gene action controlling resistance to Phytophthora infestans. Eighteen $\mathrm{F}^{1}$ families generated from two sets of 12 parents, using a North Carolina Design II, were evaluated for relative area under disease progress curve (rAUDPC), yield and yield related traits in two late blight hotspot locations of Kachwekano and Kalengyere research stations. Trials were established using an alpha lattice design $(6 \times 5)$ with two replications. Both additive and non-additive genetic effects were important in controlling yield and late blight resistance. However, additive gene action was dominant. The general combining ability (GCA) to specific combining ability ratio (SCA); (GCA/SCA) for total tuber weight and late blight resistance was 0.53 and 0.62 respectively. Broad-sense heritability estimates were 0.78 for total tuber weight and 0.68 for relative area under disease progress curve (rAUDPC). This study showed some evidence of maternal effects for rAUDPC (1.45) and average tuber weight (ATW) (1.56), although these were not significant at $\mathrm{P}<0.05$. Parents Kinigi, 392657.8, 396034.103, 396038.107, 395011.2, NKRK19.17, NKRN59.58 and 395017.14 had good GCA effects for both late blight resistance and yield related traits. Crosses of $392657.8 \times 395017.14$ and $396038.107 \times$ NKRN59.58 had the highest SCA effects for yield related traits, while families Kinigi $\times$ NKRK19.17and $392657.8 \times$ NKRN59.41 had the lowest SCA effects for rAUDPC. The relatively high heritability estimates and predominant additive genetic effects imply that genetic advances in resistance to Phytophthora infestans and tuber yield among these genotypes can be realized by selecting superior clones.
\end{abstract}

Key words: Heritability, Solanum tuberosum, gene action, rAUDPC, Phytophthora infestans resistance

Introduction

Late blight of potato caused by Phytophthora infestans (Mont.) de Bary is the most devastating disease in the tropical highlands of Uganda. The disease causes estimated yield losses between 30 and $100 \%$ in different parts of the country (Byarugaba et al., 2013). Late blight is the major reason for the use of fungicides on potatoes in Uganda (Low, 1997). As much as the disease can be managed through the use of fungicides, most small-scale farmers cannot afford them because both contact and systemic fungicides are expensive. Additionally, fungicide application is by hand. Farmers rarely use protective clothing, posing health risks and diverse environmental hazards (Kromann et al., 2009; Forbes, 2012). Consequently, there is poor disease management due to partial access to fungicides, high disease pressure and inadequate farmer knowledge of disease dynamics (Forbes, 2012). Breeding for host resistance is a sustainable approach to late blight control and management in Uganda. Though breeding for resistance to Phytophthora infestans has been a priority of the potato breeding program in Uganda over the past years. However,, previously released resistant varieties have quickly succumbed to virulent races of the pathogen (Mulema et al., 2004; Byarugaba et al., 2013).

Early efforts to breed for resistance against late blight focused on qualitative resistance controlled by major $\mathrm{R}$ genes. Even though $\mathrm{R}$ genes are greatly effective when compatible races are present, race-specific resistance controlled by major resistance ( $R$ ) genes is not considered resilient due to interminable changes in the pathogen. As a result, the focus nowadays is on quantitative, race non-specific resistance through minor resistance genes. This is more durable and effective against various pathogenic strains of Phytophthora infestans (Kumar et al., 2007) Based on this concept, the International Potato Centre (CIP) developed, a population group (B3) with quantitative resistance to Phytophthora 
infestans with no known major (R) genes. Late blight resistance in this population was improved after several cycle of recombination (B3C0, B3C1 and B3C2) (Landeo et al., 2001; Kaila, 2015). In addition, population $B 3$ genotypes have a wider genetic background for various economic traits. This germplasm is available to many developing countries for breeding purposes (Yao et al., 2011). As a result, the National Potato Program of Uganda obtained some of these clones together with the existing and adapted varieties for evaluation. The clones which were high yielding with resistance to Phytophthora infestans in the target environments were identified (Namugga et al., 2017). These were used as parents to generate new progenies with variable resistance to late blight.

In potato, both the general combining ability (GCA) effects of parents and specific combining ability (SCA) effects of their crosses are important in determining economic traits, as all genetic effects are fixed at the $F^{1}$ stage and there is no further segregation. A combining ability analysis is the basis for identification of the best parents and their crosses (Mondal and Hossain, 2006). The objectives of this study were to estimate combining ability effects and gene action for yield, yield related traits and late blight resistance. Genotypes resistant to Phytophthora infestans with high yields will be evaluated further and eventually released as varieties in Uganda.

\section{Results}

\section{Analysis of variance for crosses across sites}

The combined analysis of variance and ratio of GCA/SCA for the relative area under the disease progress curve (rAUDPC), total tuber weight (TTW) and average tuber weight (ATW) among the families are summarized in Table 1 . There were significant differences among crosses for all the traits. The environmental (site) effect was significant $(P \leq 0.01)$ for TTW and ATW. The GCA mean squares for females $\left(G C A_{f}\right)$ were significant for all traits. GCA mean squares for males $\left(G C A_{m}\right)$ were significant for all traits except ATW. The SCA effects were significant for all the tested traits. The $\mathrm{GCA}_{m} \times$ environment interaction was significant for the ATW. No significant interactions were observed between environment and sets of parents for all the traits assessed. The $\mathrm{GCA}_{f}$ effects were higher than the GCA $_{m}$ effects for rAUDPC and ATW, while additive $\mathrm{GCA}_{m}$ effects were only dominant for TTW. For ATW, SCA effects were higher than the additive main effects of either male or female parents. However, the GCA was more important than the SCA in the expression of all the traits. The ratio of additive/ non-additive genetic effects ranged from 0.38 (ATW) to 0.62 (rAUDPC).

\section{Heritability estimates and maternal effects}

The estimates of broad $\left(\mathrm{H}^{2}\right)$ and narrow -sense heritability $\left(\mathrm{h}^{2}\right)$, maternal effects for rAUDPC and yield related traits across locations are presented in (Table 2). The broad sense heritability values ranged from 0.68 to 0.78 . The narrow-sense heritability values ranged from 0.27 to 0.43 , rAUDPC had the highest value. In general, this study showed some evidence of maternal effects for some traits ( $\mathrm{rAUDPC}, \mathrm{F}=1.45$ and ATW, $\mathrm{F}$ $=1.56$ ), although these were not significant at $P \leq 0.05$.

\section{General combining ability effects of parents}

The GCA effects of potato parents at Kachwekano and Kalengyere are presented in Table 3 . Significant GCA effects were observed among all the parents for ATW. Parents Kinigi, 392657.8, 396026.103, 395017.14, NKRN59.41and 395011.2 had significant GCA effects for TTW. GCA effects for rAUDPC were significant for Kinigi, 392657.8, 395017.14, NKRK19.17, 396026.103, 396038.107, NKRN59.48 and 395011.2. Among the female parents, 396038.107 had the lowest GCA effect for rAUDPC (-1.18) followed by $392657.8(-0.82)$. Male parents NKRN59.48 (-1.9) and NKRK19.17 (-1.09) had the lowest GCA effects. For yield related traits, 392657.8 had the highest GCA effects for TTW (0.32) followed by 396026.103 TTW (0.27). For ATW, 396034.103 had the highest GCA of 0.06 followed by 396026.103 (0.03). Kinigi had the lowest GCA effect for all the yield related traits. For TTW, parent 395017.14 had the highest GCA effect for TTW (1.60) while NKRN59.41 had the lowest (0.54)

\section{Specific combining ability effects of families}

The SCA effects of 18 potato $F^{1}$ families evaluated at Kachwekano and Kalengyere are presented in Table 4. All crosses showed significant SCA effects for ATW, except Kinigi $x$ 395017.14 and 396026.103 x 395011.2. For TTW, SCA effects were significant for the crosses $396034.103 \times 395017.14$ and $393220.54 \times$ NKRN59.58. Crosses $392657.8 \times 395017.14$ and $396038.107 \times$ NKRN59.58 had the highest SCA effects for all the yield related traits (TTW and ATW). For rAUDPC, significant SCA effects were observed for crosses of $392657.8 \times$ NKRK19.17 only. The lowest SCA effects for rAUDPC were -2.29 and -1.92 for crosses Kinigi $x$ NKRK19.17and $392657.8 \times$ NKRN59.41, respectively.

\section{Family means across locations}

Means and ranking of TTW, ATW and RAUDPC within and across locations are presented in

. The mean rAUDPC (= 100 max) across locations indicated that families $393220.54 \times$ NKRN59.58 and Kinigi $x$ NKRN59.41 with disease severity of $2.5 \%$ and $4.2 \%$, respectively, were the most resistant. Families 392657.8 x 395017.14 and $396034.103 \times$ NKRK19.17 were the best yielders with a TTW of $13.3 \mathrm{t} \mathrm{ha}^{-1}$ and $11.1 \mathrm{t} \mathrm{ha}^{-1}$ respectively. Families Kinigi x NKRN59.41 (3.8) and 393220.54xNKRN59.58 (2.3) were the lowest in TTW across locations. Additionally, families $392657.8 \times 395017.14$ (96.9) and $396026.103 \times 395011.2(75.8)$ had the highest ATW across locations. Ranking of the families revealed crosses 393220.54 x NKRN59.58, Kinigi x NKRN59.41, $396038.107 \times$ NKRN59.48, $392657.8 \quad x \quad$ NKRN59.41 and $396026.103 x N K R N 59.48$ as the most resistant. The highest yielding families were $392657.8 \times 395017.14,396034.103 \times$ NKRK19.17, $396026.103 \times 395011.2,393220.54 \times 395011.2$ and $392657.8 \times$ NKRK19.17. 
Table 1: Combined analysis of variance of potato genotypes for late blight resistance, tuber yield and related traits tested at two locations in Uganda in 2017.

\begin{tabular}{|c|c|c|c|c|}
\hline \multicolumn{5}{|l|}{ Means squares } \\
\hline Source of variation & $\mathrm{DF}$ & TTW & ATW & rAUDPC \\
\hline Set $^{1}$ & 1 & 5.31 & 0.27 & 3.24 \\
\hline Site & 1 & $49.37^{* *}$ & $1.03 * *$ & 16.22 \\
\hline Site*Set & 4 & 7.40 & 0.17 & 11.8 \\
\hline Replication (Site) & 2 & $68.94 * * *$ & $1.55^{* * *}$ & $86.34 *$ \\
\hline Female (Set) & 4 & $20.22^{* *}$ & $0.40^{* *}$ & $63.12 * *$ \\
\hline Male (Set) & 4 & $32.11 * * *$ & 0.26 & $43.60 *$ \\
\hline Female*Male (Set) & 8 & $29.12 * *$ & $0.68^{* * *}$ & $40.95^{*}$ \\
\hline Site*Female (Set) & 4 & 4.11 & 0.25 & 12.81 \\
\hline Site*Male (Set) & 4 & 8.89 & $0.40^{* *}$ & 10.01 \\
\hline Site*Female*Male (Set) & 8 & 3.30 & 0.10 & 4.03 \\
\hline Error & 32 & 6.15 & 0.14 & 20.16 \\
\hline \multirow[t]{2}{*}{ R-Square } & & 0.74 & 0.72 & 0.60 \\
\hline & & 0.53 & 0.38 & 0.62 \\
\hline
\end{tabular}

${ }^{1}$ Set within an environment, $\mathrm{DF}=$ Degrees of freedom; ${ }^{*}=$ significant at $\mathrm{P} \leq 0.05 ;{ }^{* *}=$ significant at $\mathrm{P} \leq 0.01 ;{ }^{* * *}=$ significant at $\mathrm{P} \leq 0.001 ; \mathrm{TTW}=$ total tuber weight; $\mathrm{ATW}=$ average tuber weight; rAUDPC = relative area under the disease progress curve; GCA/SCA ratio calculated according to Baker (1978).

Table 2: Broad, narrow -sense heritability and maternal effects for yield related traits and rAUDPC across two locations in Uganda in 2017

\begin{tabular}{llll}
\hline Heritability/Traits & TTW & ATW & rAUDPC \\
\hline $\mathrm{H}^{2}$ & 0.78 & 0.77 & 0.68 \\
$\mathrm{~h}^{2}$ & 0.31 & 0.27 & 0.43 \\
$\mathrm{MS}_{\mathrm{F}} / \mathrm{MS}_{\mathrm{M}}$ & 0.63 & 1.56 & 1.45 \\
\hline
\end{tabular}

$\mathrm{GCA} / \mathrm{SCA}$ ratio calculated according to Baker (1978); $\mathrm{H}^{2}=$ broad sense heritability; $\mathrm{h}^{2}=$ narrow sense heritability; $\mathrm{MS}_{\mathrm{F}}=$ mean square of the female parent; $\mathrm{MS} \mathrm{S}_{\mathrm{M}}=\mathrm{mean} \mathrm{square}$ of the male parent; $\mathrm{TTW}=$ total tuber weight; ATW = average tuber weight; rAUDPC = relative area under the disease progress curve

Table 3: Estimates of general combining ability effects for, TTW, ATW and rAUDPC of 12 potato parents evaluated in two locations in Uganda in 2017.

\begin{tabular}{|c|c|c|c|}
\hline \multicolumn{4}{|l|}{ Traits } \\
\hline & TTW & ATW & rAUDPC \\
\hline \multicolumn{4}{|l|}{ Set one } \\
\hline \multicolumn{4}{|l|}{ Females } \\
\hline Kinigi & $-0.502^{* *}$ & $-0.073 * *$ & $1.201^{* *}$ \\
\hline 396034.103 & 0.177 & $0.065^{* *}$ & -0.385 \\
\hline 392657.8 & $0.324 *$ & $0.008^{* *}$ & $-0.816 *$ \\
\hline \multicolumn{4}{|l|}{ Males } \\
\hline 395017.14 & $0.315^{*}$ & $-0.019 * *$ & $1.473^{* *}$ \\
\hline NKRN59.41 & $-0.538^{* *}$ & $-0.017^{* *}$ & -0.387 \\
\hline NKRK19.17 & 0.233 & $0.037 * *$ & $-1.086 * *$ \\
\hline SE & 0.120 & 0.010 & 0.420 \\
\hline \multicolumn{4}{|l|}{ Set two } \\
\hline \multicolumn{4}{|l|}{ Females } \\
\hline 396026.103 & $0.271^{*}$ & $0.032 * *$ & $0.833^{*}$ \\
\hline 393220.54 & -0.213 & $-0.021 * *$ & 0.345 \\
\hline 396038.107 & -0.058 & $-0.011 * *$ & $-1.177 * *$ \\
\hline \multicolumn{4}{|l|}{ Males } \\
\hline NKRN59.48 & -0.150 & $-0.016 * *$ & $-1.960 * *$ \\
\hline NKRN59.58 & -0.242 & $-0.023 * *$ & 0.255 \\
\hline 395011.2 & $0.392 * *$ & $0.039 * *$ & $1.704 * *$ \\
\hline SE & 0.260 & 0.003 & 0.430 \\
\hline
\end{tabular}
$\mathrm{SE}=$ standard error; ${ }^{*}, * *$ significantly different from zero at $\geq 1.96 \mathrm{SE}$ and $2.56 \mathrm{SE}$ respectively $*=$ significant at $\mathrm{P} \leq 0.05 ; * *=$ significant at $\mathrm{P} \leq 0.01 ; \mathrm{TTW}=$ total tuber weight; ATW= average tuber weight;
rAUDPC = relative area under the disease progress curve 
Table 4: Estimates of specific combining ability (SCA) effects for TTW, ATW and rAUDPC, of $18 \mathrm{~F}^{1}$ potato families evaluated in two locations in Uganda in 2017.

\begin{tabular}{|c|c|c|c|}
\hline Traits & TTW & ATW & rAUDPC \\
\hline \multicolumn{4}{|l|}{ Set one } \\
\hline Kinigi x 395017.14 & 0.053 & -0.003 & 1.185 \\
\hline Kinigi x NKRN59.41 & -0.069 & $-0.017^{*}$ & 1.101 \\
\hline Kinigi x NKRK19.17 & 0.016 & $0.020 *$ & -2.287 \\
\hline 396034.103 x 395017.14 & $-0.690 *$ & $-0.122 * *$ & -0.627 \\
\hline 396034.103 x NKRN59.41 & 0.386 & $0.059 * *$ & 0.822 \\
\hline 396034.103 x NKRK19.17 & 0.303 & $0.063 * *$ & -0.194 \\
\hline 392657.8 x 395017.14 & 0.636 & $0.125^{* *}$ & -0.558 \\
\hline 392657.8 x NKRN59.41 & -0.317 & $-0.042 * *$ & -1.923 \\
\hline 392657.8 x NKRK19.17 & -0.319 & $-0.083 * *$ & $2.481^{*}$ \\
\hline SE & 0.660 & 0.020 & 1.260 \\
\hline \multicolumn{4}{|l|}{ Set two } \\
\hline $396026.103 \times$ NKRN59.48 & -0.418 & $0.026 * *$ & -0.498 \\
\hline $396026.103 \times$ NKRN59.58 & 0.255 & $-0.015^{*}$ & -0.556 \\
\hline $396026.103 \times 395011.2$ & 0.163 & -0.010 & 1.054 \\
\hline 393220.54 x NKRN59.48 & 0.711 & $0.031 * *$ & 0.653 \\
\hline 393220.54 x NKRN59.58 & $-0.915^{*}$ & $-0.101 * *$ & -0.858 \\
\hline 393220.54 x 395011.2 & 0.204 & $0.070 * *$ & 0.205 \\
\hline 396038.107 x NKRN59.48 & -0.294 & $-0.057 * *$ & -0.155 \\
\hline 396038.107 x NKRN59.58 & 0.661 & $0.117^{* *}$ & 1.414 \\
\hline 396038.107 x 395011.2 & -0.367 & $-0.060 * *$ & -1.259 \\
\hline SE & 0.780 & 0.010 & 1.260 \\
\hline
\end{tabular}

$\mathrm{SE}=$ standard error; ${ }^{*},{ }^{* *}$ significantly different from zero at $\geq 1.96 \mathrm{SE}$ and $2.56 \mathrm{SE}$ respectively ${ }^{*}=$ significant at $\mathrm{P} \leq 0.05 ;{ }^{* *}=$ significant at $\mathrm{P} \leq 0.01 ; \mathrm{TTW}=$ total tuber weight; $\mathrm{ATW}=$ average tuber weight; rAUDPC = relative area under the disease progress curve

Table 5: Family and parent means of total tuber weight, average tuber weight and relative area under the disease progress curve of 18 potato families evaluated at two locations in Uganda in 2017

\begin{tabular}{|c|c|c|c|c|c|c|}
\hline \multirow[b]{2}{*}{ Families } & \multicolumn{2}{|c|}{$\operatorname{TTW}\left(\mathrm{t} \mathrm{ha}^{-1}\right)$} & \multicolumn{2}{|c|}{ ATW $(g)$} & \multicolumn{2}{|c|}{ rAUDPC } \\
\hline & Mean & Rank & Mean & Rank & Mean & Rank \\
\hline Kinigi x 395017.14 & 7.7 & 14 & 40.0 & 18 & 8.5 & 18 \\
\hline Kinigi x NKRN59.41 & 3.8 & 31 & 16.6 & 31 & 4.2 & 2 \\
\hline Kinigi x NKRK19.17 & 7.2 & 18 & 45.6 & 14 & 8.0 & 15 \\
\hline $396034.103 \times 395017.14$ & 7.4 & 16 & 37.6 & 21 & 8.2 & 17 \\
\hline 396034.103 x NKRN59.41 & 8.4 & 13 & 45.7 & 13 & 9.3 & 20 \\
\hline 396034.103 x NKRK19.17 & 11.1 & 2 & 45.4 & 16 & 12.3 & 30 \\
\hline 392657.8 x 395017.14 & 13.3 & 1 & 96.9 & 1 & 14.8 & 32 \\
\hline 392657.8 x NKRN59.41 & 6.1 & 24 & 45.5 & 15 & 6.8 & 9 \\
\hline 392657.8 x NKRK19.17 & 9.2 & 8 & 57.7 & 5 & 10.2 & 23 \\
\hline 396026.103 x NKRN59.48 & 6.6 & 20 & 33.4 & 25 & 7.3 & 13 \\
\hline 396026.103 x NKRN59.58 & 8.9 & 12 & 54.9 & 8 & 9.9 & 21 \\
\hline $396026.103 \times 395011.2$ & 11.1 & 3 & 75.8 & 2 & 12.3 & 31 \\
\hline 393220.54 x NKRN59.48 & 9.2 & 9 & 52.4 & 10 & 10.2 & 24 \\
\hline 393220.54 x NKRN59.58 & 2.3 & 32 & 13.9 & 32 & 2.5 & 1 \\
\hline $393220.54 \times 395011.2$ & 9.3 & 7 & 49.3 & 11 & 10.3 & 26 \\
\hline 396038.107 x NKRN59.48 & 5.8 & 26 & 31.5 & 26 & 6.4 & 7 \\
\hline 396038.107 x NKRN59.58 & 9.2 & 10 & 56.9 & 6 & 10.2 & 25 \\
\hline $396038.107 \times 395011.2$ & 7.6 & 15 & 43.3 & 17 & 8.5 & 19 \\
\hline \multicolumn{7}{|l|}{ Parents } \\
\hline Kinigi & 9.1 & 11 & 55.7 & 7 & 10.1 & 22 \\
\hline 396034.103 & 7.3 & 17 & 48.7 & 12 & 8.1 & 16 \\
\hline 392657.8 & 4.8 & 27 & 27.8 & 27 & 5.3 & 5 \\
\hline 395017.14 & 9.9 & 6 & 53.7 & 9 & 11.0 & 27 \\
\hline NKRN59.41 & 3.9 & 30 & 24.0 & 29 & 4.4 & 3 \\
\hline NKRK19.17 & 4.8 & 28 & 27.0 & 28 & 5.3 & 6 \\
\hline 396026.103 & 4.1 & 29 & 23.8 & 30 & 4.6 & 4 \\
\hline 393220.54 & 10.3 & 5 & 67.4 & 3 & 11.4 & 28 \\
\hline 396038.107 & 6.9 & 19 & 39.6 & 20 & 7.7 & 14 \\
\hline NKRN59.48 & 6.3 & 22 & 39.8 & 19 & 7.0 & 11 \\
\hline NKRN59.58 & 6.5 & 21 & 36.7 & 23 & 7.2 & 12 \\
\hline 395011.2 & 6.2 & 23 & 37.5 & 22 & 6.9 & 10 \\
\hline Mean & 7.5 & & 44.0 & & 8.4 & \\
\hline CV (\%) & 26.5 & & 27.0 & & 30.3 & \\
\hline
\end{tabular}

TTW = total tuber weight; ATW = average tuber weight; rAUDPC = relative area under the disease progress curve 
Table 6: Correlation coefficients of yield parameters and rAUDPC in $18 \mathrm{~F}^{1}$ potato families tested at two locations in Uganda in 2017

\begin{tabular}{llll}
\hline Trait & ATW & TTW & rAUDPC \\
\hline Average tuber weight & - & & \\
Total tuber weight & $0.86 * * *$ & - & - \\
rAUDPC & $-0.86 * * *$ & $-0.99 * * *$ & - \\
\hline cant at $\mathrm{P} \leq 0.05 ; * *$ significant at $\mathrm{P} \leq 0.01 ; * * *$ significant at $\mathrm{P} \leq 0.001 ; \mathrm{TTW}=$ total tuber weight; $\mathrm{ATW}=$ average tuber weight rAUDPC = relative area under the disease progress curve
\end{tabular}

Table 7: Description of parents used in the study: CIP = International Potato Center, NARO = National Agriculture Research Organisation

\begin{tabular}{lllccc}
\hline Set & Parent & Parent type & Source & Yield (t ha- ${ }^{1}$ ) & Reaction to late blight (\% rAUDPC) \\
\hline 1 & Kinigi & Female & NARO & 32 & 32.9 \\
1 & 396034.103 & Female & CIP & 35.4 & 27.5 \\
1 & 392657.8 & Female & CIP & 43.7 & 14.1 \\
1 & 395017.14 & Male & CIP & 18.9 & 27.1 \\
1 & NKR59.41 & Male & NARO & 24.1 & 22.9 \\
1 & NKRK19.17 & Male & NARO & 37.8 & 34.1 \\
2 & 396026.103 & Female & CIP & 33.1 & 15.9 \\
2 & 393220.54 & Female & CIP & 40.3 & 36.5 \\
2 & 396038.107 & Female & CIP & 37.7 & 26.1 \\
2 & NKRN59.48 & Male & NARO & 30 & 27.7 \\
2 & NKRN59.58 & Male & NARO & 30 & 22.9 \\
2 & 395011.2 & Male & CIP & 25.5 & \\
\hline
\end{tabular}

Source: Namugga et al. (2017)

\section{Correlation among traits}

Correlations between the three traits are presented in Table 6 . Significant $(P<0.001)$ and positive correlation was found between TTW and ATW. Correlation between rAUDPC and all yield related traits were negative and significant $(P<0.001)$ for TTW and ATW.

\section{Discussion}

There was differential performance of parents and their families for the different traits between sites. The significant mean squares for families on rAUDPC and yield related traits at the two sites indicated the presence of genetic variation among parents and their crosses. This suggests that clones that are high yielding and resistant to late blight may be selected. Both additive and non-additive gene action were significant in inheritance of the traits measured. However, GCA effects were more important than SCA effects for all the traits except ATW. This implies that inheritance of these traits, except ATW, is due to additive genetic effects, hence further genetic gains can be realized by selecting superior clones.

The GCA to SCA ratio for total tuber yield was 0.53 , indicating the preponderance of additive genetic effects. Predominance of additive genetic effects observed for this trait has also been reported in previous studies (Killick, 1997; Gopal, 1998; Hirut, 2015; Muhinyuza et al., 2016). However, other studies reported both GCA and SCA to be significant for potato yield, with GCA being less important in magnitude than SCA (Ortiz and Golmirzaie, 2004; Ruiz de Galarreta et al., 2006; Haydar et al., 2009). On the other hand, some studies only reported significant SCA effects for yield (Gopal, 1998; Muthoni et al., 2015). The differences in the importance of GCA and SCA effects observed in many studies could be attributed to differences in genetic material used. For example Neele et al., (1991) and Ortiz and Golmirzaie (2004) reported GCA to be significantly greater than SCA for tuber yields and yield related traits while Muthoni et al. (2015) reported SCA effects to be greater than GCA.

The GCA/SCA ratio for RAUDPC was 0.62. This gives an indication that the additive effect was important in the expression of late blight resistance among the potato clones used. This agrees with previous reports on the relative importance of GCA and SCA for potato late blight resistance (Hirut, 2015; Muhinyuza et al., 2016). Landeo et al. (2001) reported large additive genetic variance for late blight resistance in a random sample of the $\mathrm{B} 3 \mathrm{C} 1$ population, using three different mating designs. In other studies, the SCA variances were greater than the GCA variances for late blight resistance (Kaushik et al., 2000) while Landeo et al. (2000) found both additive and non-additive genetic effects to be equally important for horizontal resistance. The dominance of additive genetic effects for late blight resistance in this study confirms the absence of major $\mathrm{R}$ genes among the parents and showed that minor genes were responsible for the resistance. All traits were highly heritable as revealed by the heritability estimates. The broad sense heritability value for rAUDPC (0.68) was similar to that reported in other studies (Christ and Hynes, 2001; Visker et al., 2004). Conversely, both broad and narrow sense $(0.43)$ heritability values were lower compared to the 0.79 and 0.78 respectively, obtained by Hynes and Christ, (1999) in a diploid hybrid potato population. Broad sense heritability values for total tuber weight $(0.78)$ and average tuber weight (0.77) were high, suggesting that genetic advances in resistance to Phytophthora infestans and tuber yield among these genotypes can be realized. Also with such large heritability estimates, it could be suggested that relatively few genes are involved. The narrow sense heritability estimates obtained differed from other findings, for example, Ortiz et al., (1997) obtained 0.54 and 0.27 for average tuber weight and marketable tuber weight, respectively. The presence of maternal effects for rAUDPC (1.45) and ATW (1.56) points to cytoplasmic inheritance, where DNA in the chloroplasts is not subject to Mendelian inheritance (Acquaah, 2012). Although these were not significant at $P \leq 0.05$, their 
presence would influence the choice of parents in a crossing scheme. Parents for improvement of these traits would be used as females.

The highly significant negative correlation between rAUDPC, and average tuber weight and total tuber weight observed in this study, shows the negative effect late blight imposes on tuber yield through the reduction of photosynthetic capacity of the foliage destruction. Several authors (Dowley et al., 2008; Mantecón, 2009; Muhinyuza et al., 2015; Hirut, 2015) have reported comparable results. Total tuber weight and average tuber weight were significantly and positively correlated (0.86). Hirut (2015) found a slightly higher correlation coefficient between total tuber weight and average tuber weight of 0.88 in combining ability studies of potato clones in Ethiopia. Mehdi et al., (2008) found total tuber yield to be largely influenced by higher number of tubers per plant and tuber size. This implies that total tuber weight can be selected for indirectly using average tuber weight.

\section{Materials and methods}

\section{Parental materials and crosses}

Twelve genetically diverse clones were selected and used as parents. Seven clones were obtained from the National Potato Program of Uganda and five were from the International Potato Centre (CIP) belonging to population $\mathrm{B} 3 \mathrm{C} 2$ with variable resistance to late blight. These parents were selected based on their flowering abilities, high to medium yields and acceptable level of resistance to Phytophthora infestans (Namugga et al., 2017). The parents were grouped into two sets of six parents based on their flowering abilities, yield and resistance to late blight. Both males and females were high yielding, resistant to late blight and good flowering abilities. Crosses were made using a North Carolina Design II (NCD II) to generate 18 families. In the first set three female clones (Kinigi, 396034.103 and 392657.8) were crossed with three males (395017.14, NKR59.41 and NKRK19.17). In the second set three female parents (396026.103, 393220.54 and 396038.107) were crossed with three males (NKRN59.48, NKRN59.58 and 395011.2). Controlled hand pollination was performed at flowering following emasculation (Acquaah, 2007). At maturity, berries of the same cross were harvested and bulked. In total, 18 families were generated (two sets of nine families each).

\section{Study sites}

Crosses to generate potato seed and the generation of seedlings were conducted at the Kachwekano research station, located in South-western Uganda, 01ㅇ 16'S 29 57'E at 2200 meters above sea level. The clonal evaluations to determine combining abilities for late blight and tuber yield and its components were conducted at Kachwekano and Kalengyere research stations. Kalengyere is located at an altitude of 2450 masl, $01^{\circ} 13.2^{\prime} \mathrm{S}, 29^{\circ} 47.8^{\prime} \mathrm{E}$. The two sites have volcanic (Andosols) soils with a bi-modal rainfall pattern separated by a dry spell ranging from 30-60 days. These locations have the same pathogen population (Njoroge et al., 2016) and are known to experience severe late blight disease pressure during the rainy season. Consequently, clones were evaluated under natural disease infestation.

\section{Experimental design and trial establishment}

Experiments were established during the main planting season of 2017A (March-June). Planting was done on the 14th and 16th of March 2017 at Kalengyere and Kachwekano, respectively. To increase the disease inoculum, a susceptible variety (Victoria) was planted adjacent to each row and around each replication as spreader rows. No control measure was taken against late blight. Trials were established using an alpha lattice design $(6 \times 5)$ with two replications. Each entry was represented by an experimental unit consisting of 40 plants assigned in a plot size of two rows of $4.5 \mathrm{~m}$ long at spacing of $0.75 \mathrm{~m} \times 0.3 \mathrm{~m}$. All the necessary agronomic practices were carried out as recommended.

\section{Data collection}

Data were collected on reaction to late blight infection and yield related traits. Late blight assessment started with the first appearance of the symptoms. Plants were visually rated at seven day intervals for percentage leaf and stem area with late blight lesions. This was done visually by comparing the green and non-green leaf portions affected by the disease using a 1 to 9 scale designed by the International Potato Centre, that is, $1=0 \%, 2=2.5 \%, 3=10 \%, 4=25 \%, 5=50 \%, 6=75 \%, \quad 7=90 \%$, $8=97.5 \%$ and $9=100 \%$ leaf area showing disease symptoms (Henfling, 1987). The mean percentage blighted foliar area per plot was calculated. Evaluations continued until the susceptible genotype reached $90-100 \%$ of leaf blight assessments and the area under the disease progress curve (AUDPC) was calculated (Campbell and Madden, 1990). The relative area under the disease progress curve (rAUDPC) was used in the analysis of variance. The rAUDPC was calculated using the following formula:

$r A U D P C=\sum \frac{\left(T_{i+1}-T_{i}\right) *\left(\frac{D_{i+1}+D_{i}}{2}\right)}{T_{T o t a l} * 100} \quad$ (Equation 1)

In equation $1, \mathrm{~T}_{\mathrm{i}}=$ is the $i^{\text {th }}$ day when an estimation of percentage foliar late blight is made and $D_{i}=$ is the estimated percentage of area with blighted foliage at $T_{i}$. The total is the number of days at which the final assessment was recorded. At harvest, yield related data was taken for total weight of all the tubers harvested in a plot (TTW) and expressed in $\mathrm{t} \mathrm{ha}{ }^{-1}$. Average tuber weight (ATW) was calculated as the total tuber weight per plant divided by the total tuber number of tubers per plant.

\section{Data analyses}

\section{Analysis of variance}

Data for the different traits over the two sets and across environments were subjected to the standard analysis of variance using the GLM procedure of SAS 9.3 (SAS Institute Inc, 2011) statistical program. Analyses of variance of NCD II pooled over sets and across environments were conducted for 
rAUDPC and yield. Spearman correlation coefficients were calculated for the studied traits to determine their association.

\section{Estimation of general and specific combining ability effects}

GCA and SCA effects were estimated using the following linear model (Hallauer and Miranda, 1988).

$\mathrm{Y} i j k p q=\mu+\mathrm{S} p+\mathrm{g} j(\mathrm{~S} p)+\mathrm{gj}(\mathrm{S} p)+\mathrm{hij}(\mathrm{S} p)+\mathrm{E} q+\mathrm{rk}(\mathrm{SE}) p q+(\mathrm{ES}) p q$ $+(\mathrm{E} g) i q(\mathrm{~S} p)+(\mathrm{E} g) j p(\mathrm{~S} p)+(\mathrm{E} h) i j q(\mathrm{~S} p)+(\mathrm{E} h) i j q(\mathrm{~S} p)+\mathrm{e} i j k p q$

Where: $i=1,2,3 ; j=1,2,3 ; k=1,2 ; p=1,2 ; q=1,2$; the terms for the model are defined as follows: $Y_{i j k p q}$ denotes the value of a family from the mating between the $i^{\text {th }}$ female parent, the $j^{\text {th }}$ male parent, in the $k^{\text {th }}$ block, within set $p$ and in the $q^{\text {th }}$ environment; $\mu=$ grand mean; $S p=$ the average effect of the $p^{\text {th }}$ set; $g i(S p)=$ the GCA effect common to all $F^{1}$ families of the $i^{\text {th }}$ female parent nested within $p^{\text {th }}$ set; $g j(S p)=$ the GCA effect common to all $\mathrm{F}^{1}$ families of the $j^{\text {th }}$ male parent nested within $p^{\text {th }}$ set; $\mathrm{h}_{i j}(\mathrm{~S} p)=$ the SCA effect specific to $\mathrm{F}^{1}$ families of the $i^{\text {th }}$ female and $j^{\text {th }}$ male parent nested within $p^{\text {th }}$ set; $E q=$ average effect of $q^{\text {th }}$ environment; $r k(\mathrm{SE}) p q=$ the effect of the $k^{\text {th }}$ replication nested within the $p^{\text {th }}$ set and $q^{\text {th }}$ environment; $(\mathrm{ES}) p q=$ the interaction between site and set effects; $(\mathrm{E} g) i q(\mathrm{~S} p)$ and $(E g) j p(S p)=$ the interaction between site and GCA of the $i^{\text {th }}$ female and $j^{\text {th }}$ male parent, respectively nested within sets; $(E h) i j q(S p)=$ the interaction between site and SCA, nested within sets; and $\mathrm{e}_{i j k p q}=$ the random experimental error.

The relative importance of GCA and SCA effects for each trait was determined according to the general predicted ratio (GPR) as follows: GCA $/ S C A=2 M S G C A /(2 M S G C A+M S S C A)$ (Baker, 1978). When the GCA/SCA ratio is greater than 0.5 , additive effects are more important than non-additive effects in the inheritance of the concerned trait, whereas if the ratio is smaller than 0.5 , dominance effects are more important in the inheritance of the concerned character.

\section{Estimating heritability and maternal effects}

Heritability estimates were calculated using the female additive variance for both narrow and broad sense heritability (Dabholkar, 1999) as follows: Narrow sense heritability; $h_{f}^{2}=$ $4 \sigma_{f}^{2} /\left(\sigma^{2}{ }_{e} / r+4 \sigma_{m f}^{2}+4 \sigma_{f}^{2}\right)=V_{A f} / V_{P}$; broad sense heritability; $h_{f}^{2}=4 \sigma_{f+}^{2} 4 \sigma_{m f}^{2} /\left(\sigma_{e}^{2} / r+4 \sigma_{m f}^{2}+4 \sigma_{f}^{2}\right)=V_{G f} / V_{P}$. Where, $r=$ number of replication

$\sigma^{2}{ }_{e}=$ environmental variance $=M_{e}$

$\sigma^{2}{ }_{f}=$ variance of female parents $=G_{C A}$ variance $=M_{f}$

$\sigma^{2}{ }_{\mathrm{fm}}=$ variance due to interaction between females and males $=\mathrm{SCA}$ variance $=\mathrm{MS}_{\mathrm{mf}}$

$\mathrm{V}_{\mathrm{Af}}=$ additive genetic variance due to female parents

$V_{P}=$ phenotypic variance

$\mathrm{V}_{\mathrm{Gf}}=$ total genetic variance

Test for maternal effects: The ratio of $\mathrm{MS}_{\mathrm{f}}$ : $\mathrm{MS}_{\mathrm{m}}$ estimates the levels of maternal effects provided $f=m$ in the design.

$\mathrm{F}=\mathrm{MS}_{\mathrm{f}} / \mathrm{MS}_{\mathrm{m}}, \mathrm{F}_{\mathrm{m}}, \mathrm{f}$ degrees of freedom at $\mathrm{P}<0.05$. If the ratio is greater than 1 there is ample evidence to suggest presence of maternal effects.

\section{Conclusions}

The significant differences observed among general combining ability $\left(\mathrm{GCA}_{\mathrm{f}}\right.$, and $\left.\mathrm{GCA}_{\mathrm{m}}\right)$, and specific combining ability (SCA) effects for the genotypes suggest the presence of sufficient genetic variation, which can be exploited for crop improvement. This study found additive gene action to be more important than non- additive genetic effects in the inheritance of yield related traits and resistance to late blight disease in potato. This signifies that improvement can be made by selection and traits transferred to the respective progenies. The best general combiners were 393220.54, Kinigi, 395011.2, 392657.8, 396026.103, NKRN59.48 and NKRN59.58. Families: 393220.54 x NKRN59.48, 396038.107 x NKRN59.58, $392657.8 \times$ 395017.14, Kinigi $x$ NKRK19.17 and $392657.8 \times$ NKRN59.41 had desirable SCA effects for yield and resistance to Phytophthora infestans. The selected parents can be used for crop improvement purposes.

\section{Acknowledgements}

The Alliance for a Green Revolution in Africa (AGRA) is sincerely thanked for funding this study. Due thanks to the National Agricultural Research Organization (NARO) for all the support rendered to the first author.

\section{Conflict of Interest Statement}

"The authors declared that they have no conflict of interest".

\section{References}

Acquaah G (2007) Principles of plant genetics and breeding. Blackwell, Maden.

Acquaah G (2012) Principles of plant genetics and breeding. Second edition ed. Wiley -Black Well.

Baker RJ (1978) Issues in diallel analysis. Crop Sci. 18:533-536.

Byarugaba AA, Namugga P, Kashaija IN (2013) Identification of potato clones of population B3C2 with durable field resistance to late blight (Phytophthora infestans) and high yields in Uganda. Afri Agric Res. 8: 3055-3059.

Campbell CL, Madden LV (1990) Introduction to plant disease epidemiology. New York: Wiley.

Christ BJ, Haynes KG (2001) Inheritance of resistance to early blight disease in a diploid potato population. Plant Breeding. 120: 169-172.

Dabholkar AR (1999) Elements of biometrical genetics. Concept Publishing Company, New Delhi.

Dowley LJ, Grant J, Griffin D (2008) Yield losses caused by late blight (Phytophthora infestans (Mont.) de Bary) in potato crops in Ireland. Irish J Agr Food Res. 47:69-78.

Forbes $\mathrm{G}$ (2012) Using host resistance to manage potato late blight with particular reference to developing countries. Potato Res. 55: 205-216.

Gopal J (1998) General combining ability and its repeatability in early generations of potato breeding programs. Potato Res. 41: 21-28.

Hallauer AR, Miranda LB (1988) Quantitative genetics in maize breeding, 2nd edn. lowa State University Press, Ames.

Hallauer AR, Carena MJ, Filho JBM (1988) Hereditary variance: mating designs. In: Quantitative genetics in maize breeding. lowa State University, Ames, pp 81-167.

Haydar A, Alam MK, Khokan EH, Ara T, Khalequzzaman KM (2009) Combining ability and genetic variability studies in potato. Journal of Soil Nature. 3:1-3. 
Haynes. KG, Christ BJ (1999) Heritability of resistance to foliar late blight in a diploid hybrid potato population of Solanum phureja x Solanum stenotomum. Plant Breeding. 118: 431434.

Henfling JW (1987) Late blight of potato: Phytophthora infestans. Technical Information

bulletin pp.25. International Potato Center. Lima.

Hirut GB (2015) Genetic analyses of drought tolerance and resistance to late blight among potato genotypes. PhD thesis, University of KwaZulu-Natal, South Africa.

Kaila L (2015) Inheritance and stability of late blight resistance in potato population B3 of the International Potato Centre. M.Sc. Thesis. University of Helsinki, Finland.

Kaushik S, Birhman R, Singh B, Gopal J (2000) Combining ability and heterosis for field resistance to late blight in potato (Solanum tuberosum). Indian J Agr Sci. 70: 55-56.

Killick RJ (1997) Genetic analysis of several traits in potatoes by means of a diallel cross. Ann Appl Biol. 86:279-289.

Kromann P, Taipe A, Perez WG, Forbes GA (2009) Rainfall thresholds as support for timing fungicide applications in the control of potato late blight in Ecuador and Peru. Plant Dis. 93: 142-148.

Kumar R, Kang GS, Pandey SK (2007) Inheritance of resistance to late blight

(Phytophthora infestans) in potato. Euphytica. 155:183-191.

Landeo J, Gastelo M, Roncal E, Mendoza A (2000) Phenotypic stability for horizontal resistance to potato late blight in population B. Am J Potato Res. 77:406.

Landeo J, Gastelo M, Beltran G, Diaz L (2001) Quantifying genetic variance for horizontal resistance to late blight in potato breeding population B3C1. In Scientist and farmer: Partners in Research for the 21st century. Program report, 1999-2000, CIP, Lima, Peru. 63-68.

Low J (1997) Potato in southwest Uganda: threats to sustainable production. Afr Crop Sci J. 5: 395-412.

Mantecón JD (2009) Importance of potato late blight in Argentina, and the effect of fungicide treatments on yield increments over 20 years. Cienc Investig Agrar. 36: 115-122.

Mehdi M, Saleem T, Rai HK, Mir MS, Rai G (2008) Effect of nitrogen and FYM interaction on yield and yield traits of potato genotypes under Ladakh condition. Potato Journal. 35: 126-129.

Muhinyuza JB, Shimelis H, Melis R, Sibiya J, Gahakwa D, Nzaramba MN (2015) Yield response and late blight reaction of potato genotypes in Rwanda. Am J Potato Res. 77 92: 1022.
Muhinyuza JB, Shimelis H, Melis R, Sibiya J, Gahakwa D, Nzaramba MN (2016) Combining ability analysis of yield and late blight [Phytophthora infestans (Mont.) de Bary] resistance of potato germplasm in Rwanda. Aust J Crop Sci. 10:799-807.

Mondal MA, Hossain MM (2006) Combining ability in potato (Solanum tuberosum L.). Bangladesh J Botany. 35:125-131.

Mulema J, Olanya O, Adipala E, Wagoire W (2004) Stability of late blight resistance in population $B$ potato clones. Potato Res. 47: 11-24.

Muthoni J, Shimelis H, Melis R (2015) Combining ability analysis of tuber yield and related traits and bacterial wilt (Ralstonia solanacearum) resistance in potato. Aust J Crop Sci. 9:401-412.

Namugga P, Sibiya J, Melis R, Barekye A (2017) Phenotypic characterisation of potato (Solanum tuberosum L.) genotypes in Uganda. South African Journal of Plant and Soil. 35:1-8.

Njoroge AW, Tusiime G, Forbes GA, Yuen JE (2016) Displacement of US-1 clonal lineage by a new lineage of Phytophthora infestans on potato in Kenya and Uganda. Plant Pathol. 65: 587-592.

Neele AEF, Nab HJ, Louwes KK (1991) Identification of superior parents in a potato breeding program. Theor Appl Genet. 82:264-272.

Ortiz R, Golmirzaie AM (2004) Combining ability analysis and correlation between breeding values in true potato seed. Plant Breeding. 123:564-567.

Ortiz R, Iwanaga M, Peloquin SJ (1997) Evaluation of FDR diploid and tetraploid parents in potato under two different day-length environments. Plant Breeding. 116:353-358.

Ruiz de Galarreta JJ, Ezpeleta B, Pascualena J, Ritter E (2006) Combining ability and correlations for yield components in early generations of potato breeding. Plant Breeding. 125:183-186.

SAS Institute (2011) SAS software release 9.1.3. SAS Institute Inc., Cary, NC. USA.

Visker MHPW, van Raaij HMG, Keizer LCP, Struik PC, Colon LT (2004) Correlation between late blight resistance and foliage maturity type in potato. Euphytica. 137: 311-323.

Yao C-G, Song BT, Jun L, Wu C-J, Cheng Q, Li D-C, Xie C-H (2011) Population improvement of resistance to late blight in tetraploid potato: A case study in combination with AFLP marker assisted background selection. Agric Sci China. 10: 1177-1187. 